\title{
Salivary Azurocidin and Tumor Necrosis Factor-a Levels in Patients with Stage III-IV, Grade C Periodontitis
}

\author{
Evre III-IV, Derece C Periodontitis Hastalarında Tükürük Azurosidin ve \\ Tümör Nekroz Faktör- $\alpha$ seviyeleri
}

\author{
Beral AFACAN ${ }^{1 *}$, Harika ATMACA ÍLHAN ${ }^{2}$
}

${ }^{1}$ Aydın Adnan Menderes University, School of Dentistry, Department of Periodontology, Aydın, Turkey. Orcid: 0000-0003-2581-1400 ${ }^{2}$ Manisa Celal Bayar University, Faculty of Science and Letters, Section of Molecular Biology, Department of Biology, Manisa, Turkey. Orcid: 0000-0002-8459-4373

Atıf/Citation: Afacan, B. \& Atmaca, İlhan, H. (2020). Salivary Azurocidin and Tumor Necrosis Factor- $\alpha$ Levels in Patients with Stage III-IV, Grade C Periodontitis. Ege Üniversitesi Diş Hekimliği Fakültesi Dergisi, 41(1), 47-54.

\begin{abstract}
Objective: Azurocidin, a neutrophil granule-derived antimicrobial protein, plays an important role in host-pathogen interactions and immunoregulation. Periodontitis is a polymicrobial inflammatory disease caused by the host response to subgingival microbiota. This study aimed to evaluate salivary azurocidin and tumor necrosis factor (TNF)- $\alpha$ levels in patients with stage III-IV, grade Cperiodontitis.
\end{abstract}

Methods and Materials: In total 78 systemically healthy individuals (40 periodontitis (stage III-IV, grade C) and 38 periodontally healthy) were enrolled. Saliva samples were collected and clinical periodontal measurements including probing depth $(P D)$, clinical attachment loss $(C A L)$, the percentage of sites with bleeding on probing (BOP \%), gingival index (GI) and plaque index (PI) were recorded. Salivary azurocidin and TNF-a levels were measured by ELISA.

Results: Periodontitis group exhibited higher PD, CAL, BOP (\%), GI and PI values compared to the periodontally healthy group $(p<0.001)$. Salivary azurocidin and TNF- $\alpha$ concentrations in periodontitis group were significantly higher than healthy controls $(p<0.05)$. There were positive correlations among azurocidin, TNF- $\alpha$ and all clinical periodontal parameters $(p<0.001)$.

Conclusion: Present findings suggest that salivary azurocidin and TNF- $\alpha$ levels may involved in periodontal inflammation and may be useful in the diagnosis of periodontal diseases. Further studies are needed to enlighten the role of these molecules in the pathogenesis of periodontal disease.

Key words: Periodontitis, inflammation, saliva, cytokine

$\ddot{O Z Z}$

Amaç: Azurosidin, nötrofillerin granüllerinde sentezlenen, konak-patojen etkileşimlerinde ve immunregülasyonda önemli rol oynayan antimikrobiyal bir proteindir. Periodontitis, subgingival mikrobiyotaya karşı gelişen konak yanıtından kaynaklanan polimikrobiyal enflamatuvar bir hastalıktır. Bu araştırma, evre III-IV, derece C periodontitis hastalarında tükürük azurosidin ve tümör nekroz faktör (TNF)-a seviyelerini değerlendirmeyi amaçlamaktadır.

Yöntem: Çalışmaya sistemik sağııkı toplam 78 birey (40 periodontitis (evre III-IV, derece C) ve 38 sistemik sağlıklı) dahil edildi. Tükürük örnekleri toplandı ve sondalama derinliği (SD), klinik ataşman kaybı (KAK), sondalamada kanama yüzdesi (SK \%), gingival indeks (GI) ve plak indeksini (PI) içeren klinik periodontal ölçümler kaydedildi. Tükürük azurosidin ve TNF- $\alpha$ seviyeleri ELISA ile ölçüldü.

Bulgular: Periodontitis grubunun SD, KAK, SK (\%), Gi ve Pi değerleri, periodontal sağlıklı gruptan anlamlı yüksek bulundu ( $p<0.001)$. Periodontitis grubunun tükürük azurosidin ve TNF- $\alpha$ konsantrasyonları, periodontal sağlıklı gruptan anlamlı yüksekti $(p<0.05)$. Azurosidin, TNF- $\alpha$ ve tüm klinik periodontal parametreler arasında anlamlı pozitif korelasyonlar gözlendi $(p<0.001)$.

Sonuç: Bu çalışmanın bulguları, tükürük azurosidin ve TNF- $\alpha$ seviyelerinin periodontal enflamasyon ile ilişkiliolabileceğini ve periodontal hastalıkların tanısında yarar sağlayabileceğini düşündürmektedir. Bu moleküllerin, periodontal hastalık patogenezindeki rollerine ilişkin daha ileri çalışmalara ihtiyaç vardır.

Anahtar Kelimeler: Periodontitis, enflamasyon, tükürük, sitokin

Sorumlu yazar/Corresponding author*: beral.afacan@adu.edu.tr

Başvuru Tarihi/Received Date: 18.11.2019

Kabul Tarihi/Accepted Date: 28.01.2020 


\section{INTRODUCTION}

Periodontitis is a chronic inflammatory disease characterized by irreversible destruction of connective tissue attachment and alveolar bone, eventually leading to tooth $\operatorname{loss}^{1}$. It has been generally accepted that periodontal tissue breakdown results from the complex interaction between subgingival pathogenic bacteria and host immunoinflammtory response $e^{2}$. Periodontal pathogens, especially Gram-negative anaerobic bacteria ${ }^{3}$, activate host cells to produce proinflammatory mediators such as tumor necrosis factor (TNF)- $\alpha$, interleukin (IL)$1 \beta$ and IL-6 and proteolytic enzymes, which in turn promote the destruction of periodontal tissues ${ }^{2}$.

Neutrophils are the most abundant leukocytes recruited to the gingival sulcus in response to bacterial biofilm. ${ }^{2,4}$ They respond to bacterial products by microbial killing via oxygen-dependent and oxygen-independent mechanisms. ${ }^{4}$ The non-oxidative antibacterial mechanisms involve a diverse group of antimicrobial peptides ${ }^{5}$ which play a role in periodontal inflammation and wound healing. ${ }^{6,7}$ Azurocidin is also a $37 \mathrm{kDa}$ cationic antimicrobial protein expressed in azurophil granules of neutrophils. ${ }^{8}$ It is considered to be inactive serine protease homologou due to the lack of its proteolytic activity. Azurocidin exhibits broad spectrum of antimicrobial activity, particularly against Gram-negative bacteria. ${ }^{10} \mathrm{It}$ also has chemotactic effects on monocytes/macrophages and $\mathrm{T}$ cells and enhances macrophage phagocytosis. ${ }^{9}$ Moreover, the release of TNF- $\alpha$ and IL-6 from monocytes in response to lipopolysaccharide (LPS) is induced by azurocidin. ${ }^{9,11}$

Earlier studies have reported that azurocidin is a marker of a worse prognosis in sepsis and acute respiratory distress syndrome. ${ }^{12}$ Elevated salivary azurocidin levels were observed in patients with type 1 diabetes mellitus with retinopathy and/or nephropathy. ${ }^{13}$ Therefore, it might be potential screening targets for diabetes mellitus complications. ${ }^{13}$ To date, there is limited data on the relationship between azurocidin and periodontal condition. Choi et al. ${ }^{14}$ demonstrated for the first time the presence of azurocidin in gingival crevicular fluid (GCF) of chronic periodontitis patients by proteomic analysis. The authors validated the elevated GCF azurocidin levels in these patients by ELISA. Leppilahti et al. ${ }^{15}$ found higher GCF azurocidin levels in chronic periodontitis compared to gingivitis and healthy sites which were also positively correlated with expression of collagenolytic matrix metalloproteinases. Guzman et al. ${ }^{16}$ suggested that azurocidin might be the strongest candidate biomarker for periodontitis due to decreased GCF azurocidin levels following non-surgical periodontal treatment.

Saliva, an important physiological fluid, has been proposed as a non-invaziv diagnostic medium that could be used in the diagnosis of oral and systemic diseases..$^{17}$ Whole saliva is a complex mixture derived from not only major and minor salivary glands but also GCF that contains products of inflammation ongoing in periodontium..$^{18}$ It has been suggested that GCF is the primary source of periodontitis-associated cytokines in whole saliva. ${ }^{19}$ Analyses of inflammatory biomarkers in saliva could serve as an attractive tool for the diagnosis of periodontal diseases. ${ }^{18}$ Various enzymes, cytokines and biomarkers that are involved in periodontal tissue breakdown have been found to be elevated in saliva of periodontitis patients in comparison with periodontally healthy controls. ${ }^{17-19}$ Considering the possible relationship between azurocidin and periodontal inflammation ${ }^{14-16}$, it was hypothesized that salivary azurocidin and TNF- $\alpha$ levels increase in periodontitis patients. The aim of this study was to investigate whether salivary azurocidin levels could be used as a discriminatory biomarker to distinguish periodontally healthy and periodontal diseased individuals.

\section{MATERIALS AND METHODS}

\section{Study Population and Clinical Examination}

A total of 78 individuals (38 females and 40 males; age range 30-46 years) seeking dental treatment in the School of Dentistry, Adnan Menderes University, Aydın, Turkey, were recruited for the present study from March to October of 2019. The protocol was approved by the Ethics Committee of the School of Dentistry, Adnan Menderes University with the protocol number (No: ADÜDHF2019/053) and the research was conducted in compliance with the Declaration of Helsinki (version 2008). The purpose and procedures of the study were explained and written informed consent was received from each participant prior to participation.

A comprehensive medical and dental history was taken on all participants with an oral examination. All participants were never smokers. Each individual had at least 20 natural teeth. Patients were excluded from the study if they were suffering from any chronic inflammatory or immunological conditions such as diabetes mellitus, cardiovascular diseases, rheumatoid arthritis and mucocutaneous diseases. None of the females were pregnant or lactating. Individuals who took 
medications such as antimicrobials, anti-inflammatory drugs and immunosuppressive agents within 4 months before study entry were also excluded. Participants had not undergone nonsurgical/surgical periodontal therapy in the preceding 12 months. Individuals who had orthodontic appliances, removable partial dentures and restorative and endodontic treatment requirements were not included in this study.

Probing depth (PD), clinical attachment loss (CAL), gingival index $(\mathrm{GI})^{20}$, the percentage of sites with bleeding on probing (BOP \%) and plaque index (PI) ${ }^{21}$ were assessed during periodontal clinical examinations. All measurements were obtained in 6 sites per tooth, except the third molars, using a manual periodontal probe (William's periodontal probe, Hu-Friedy, Chicago, IL) by a single trained examiner (BA). PD and CAL were determined by the distance from reference point to bottom of pocket using reference as gingival margin and cement-enamel junction respectively. As an indicator of oral hygiene, PI is determined by the Quigley-Hein Plaque Index as modified by Turesky ${ }^{21}$. The alveolar bone resorption was assessed on the digital panoramic radiograph in each participant.

According to the diagnostic criteria proposed by the 2017 International Workshop on the Classification of Periodontal and Peri-implant Diseases and Conditions ${ }^{22}$ participants were categorized into two distinct groups based upon their periodontal status: 1) 40 patients with generalized stage III-IV, grade C periodontitis 2) 38 periodontally healthy individuals. The severity of periodontitis was defined by the amount of CAL. These patients had at least two interdental sites (at two non-adjacent teeth) with $\mathrm{CAL} \geq 5 \mathrm{~mm}$. Care was taken to ensure that CAL was not caused by non-periodontal causes such as dental caries extending in the cervical area of the tooth, gingival recession of traumatic origin, the presence of CAL on the distal aspect of a second molar due to extraction of a third molar, an endodontic lesion draining through the marginal periodontium and the occurrence of a vertical root fracture.The complexity of periodontitis was defined by $\mathrm{PD}$ and furcation involvement. These patients had $\mathrm{PD} \geq 6 \mathrm{~mm}$ at least two interdental sites (at two non-adjacent teeth) and also Class II-III furcation involvement. Considering the extend and distribution of periodontitis, these patients had CAL at $\geq$ 30 of teeth involved.

The grading of periodontitis was evaluated indirect evidence of progression through \% bone loss/ age. Radiographic alveolar bone loss (RBL) of each natural tooth was assessed by using the panoramic radiograph. It was recorded by measuring the mesial and distal of the remaining teeth (except the 3rd molars) from the cemento-enamel junction of the tooth up to the highest point of the proximal alveolar bone crest. The most extensive bone loss (\%) (RBL expressed as percentage of root length) was determined and \% bone loss/age were calculated. When this value was $>1.0$, participants were included in Grade C.

Periodontally healthy individuals in the control group had an intact periodontium (without detectable CAL or RBL) or a reduced periodontium in a non-periodontitis patient. In this group, PD was $\leq 3 \mathrm{~mm}$ and BOP was $<10$ $\%$ in the whole mouth.

\section{Saliva Collection}

All samples were collected before clinical measurements. Unstimulated whole saliva obtained from the participants in the morning between 8:00 am-9:30 am after an overnight fast. A modification of the method described by Navazesh ${ }^{23}$ was used for saliva collection. All individuals were asked to avoid any oral care practice such as brushing, interdental cleaning and rinsing with mouthwash before collection. Each participant was requested first to rinse the mouth completely with tap water for 2 minutes and to wait for 10 minutes. Then, the participants were asked to let the saliva pool in their floor of the mouth and to allow the saliva to drain passively into a sterile plastic container for 5 minutes. Saliva samples were held on ice and then stored at $-40^{\circ} \mathrm{C}$, until the analysis.

\section{Measurement of Azurocidin and TNF- $\alpha$ Levels in Saliva Samples}

On the day of analysis, frozen saliva samples were thawed on ice and centrifuged at $10000 \mathrm{x} \mathrm{g}$ for 15 minutes at $4{ }^{\circ} \mathrm{C}$. Azurocidin and TNF- $\alpha$ concentrations in saliva samples were determined by the enzyme-linked immunosorbent assay (ELISA) using commercial kits (Human Azurocidin and TNF- $\alpha$ ELISA kits, Sunred Biotechnology, Shanghai) in accordance with the manufacturer's guidelines. The minimum detection limits in the assays were $0.25 \mathrm{ng} / \mathrm{ml}$ for azurocidin and $3 \mathrm{ng} / \mathrm{L}$ for TNF- $\alpha$. Absorbance was measured at $450 \mathrm{~nm}$ with $650 \mathrm{~nm}$ as a reference wavelength by an automated ELISA plate reader (DTX 880 Multimode Reader, Beckman Coulter, Miami, FL). Cytokine concentrations were determined from the standard curve. Salivary concentrations of azurocidin and TNF- $\alpha$ were presented as $\mathrm{ng} / \mathrm{ml}$ and $\mathrm{ng} / \mathrm{L}$, repectively. 


\section{Statistical Analysis}

The sample size was calculated using a specialized software package (G*Power version 3.0.8, Heinrich Heine University, Düsseldorf) for power analysis. This analysis was performed on the basis of the findings of a study by Choi et al. ${ }^{15}$ Considering a significant difference between two study groups for GCF azurocidin levels at 0.67 effect size (d) and at $\alpha=0.05$ significance level with a power of $80 \%$ using an independent samples T-test (difference between the means in two unrelated groups) the minimum sample size required was 36 in each group.

All data analyses were performed using a statistical package(SPSSv25.0, IBM, Chicago, IL.) Thedistribution of the clinical and biochemical data was validated by Shapiro Wilk's normality test. Comparisons of clinical and biochemical parameters between the study groups were performed using the independent two samples T- test. Chi-square analysis was used to compare the proportion of genders between groups. The correlations among salivary azurocidin and TNF- $\alpha$ levels and clinical periodontal parameters were determined by Spearman rank correlation analysis. Statistical significance was considered at $\mathrm{p}<0.05$ for all the tests.

\section{RESULTS}

The demographic characteristics and whole mouth clinical periodontal parameters are presented in Table 1. There were no statistical differences in terms of age and gender distribution between periodontitis and periodontally healthy groups $(\mathrm{p}=0.299$ for age; $\mathrm{p}=0.825$ for gender distrubition). The mean PD and CAL values of periodontitis patients were significantly higher than those of healthy individuals ( $p<0.001)$. PI, GI and BOP (\%) scores were also significantly higher in the diseased group compared to the healthy controls $(\mathrm{p}<0.001)$.

Azurocidin was detected in all saliva samples. Salivary azurocidin concentrations $(\mathrm{ng} / \mathrm{ml})$ of the studied groups were shown Figure 1. Periodontitis group had significantly higher salivary azurocidin levels compared to healthy controls ( $\mathrm{P}=0.006)$.

Salivary TNF- $\alpha$ concentrations (ng/L) of study groups were demonstrated Figure 2. TNF- $\alpha$ was also detected in all saliva samples. Periodontitis group had significantly higher salivary TNF- $\alpha$ levels compared to healthy controls $(\mathrm{P}<0.001)$.

Salivary azurocidin and TNF- $\alpha$ concentrations showed significant positive correlations with all clinical periodontal parameters ( $\mathrm{P}<0.05$, Table 2 ). There was also a positive correlation between azurocidin and TNF- $\alpha$ levels in saliva ( $r=0.376, \mathrm{p}<0.001$, Table 2$)$.

Table 1. The demographic characteristics and whole-mouth clinical periodontal parameters of the study groups.

\begin{tabular}{llll}
\hline & $\begin{array}{l}\text { Periodontitis } \\
(\mathrm{n}=40)\end{array}$ & $\begin{array}{l}\text { Periodontal Health } \\
(\mathrm{n}=38)\end{array}$ & p- value \\
\hline Demographic variables & & & \\
Age (years) & $37.75 \pm 4.53$ & $36.68 \pm 4.46$ & 0.299 \\
Sex (Female / Male) & $19 / 21$ & $19 / 19$ & 0.825 \\
Periodontal parameters & & & $<0.001$ \\
PD (mm) & $4.43 \pm 0.58^{*}$ & $1.66 \pm 0.18$ & $<0.001$ \\
CAL (mm) & $5.39 \pm 0.82^{*}$ & $0.02 \pm 0.02$ & $<0.001$ \\
BOP (\%) & $82.40 \pm 5.58^{*}$ & $1.78 \pm 1.09$ & $<0.001$ \\
GI & $2.34 \pm 0.28^{*}$ & $0.03 \pm 0.01$ & $<0.001$ \\
PI & $3.54 \pm 0.34^{*}$ & $1.73 \pm 0.41$ & \\
\hline
\end{tabular}

All data (except for sex) are given as mean $\pm \mathrm{SD}$. ${ }^{*} \mathrm{p}<0.001$, significantly higher than periodontally healthy group. PD: Probing depth, CAL: Clinical attachment loss, GI: Gingival index, BOP: Bleeding on probing, PI: Plaque index. 
Table 2. Correlations of s alivary azurocidin and TNF - $\alpha$ levels with clinical per iodontal parameters and each others.

\begin{tabular}{clll}
\hline Variables & & Azurocidin & TNF- $\alpha$ \\
\hline PD & r & $0.261^{*}$ & $0.597^{* *}$ \\
CAL & r & $0.228^{*}$ & $0.553^{* *}$ \\
BOP (\%) & r & $0.357^{* *}$ & $0.795^{* *}$ \\
GI & r & $0.339^{* *}$ & $0.765^{* *}$ \\
PI & r & $0.267^{*}$ & $0.570^{* *}$ \\
Azurocidin & r & & $0.376^{* *}$ \\
TNF- $\alpha$ & r & $0.376^{* *}$ & \\
\hline
\end{tabular}

* Correlation is significant at the 0.05 level. **Correlation is significant at the 0.01 level.

PD: Probing depth, CAL: Clinical attachment loss, BOP: Bleeding on probing,

GI: Gingival index, PI: Plaque index, TNF- $\alpha$ : Tumor necrosis factor- $\alpha$.

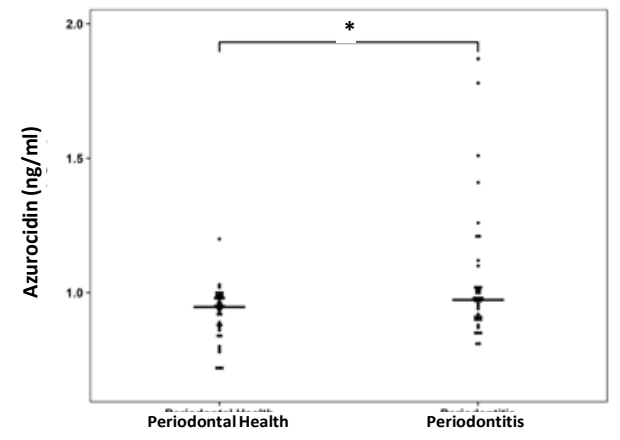

Figure 1: Saliva azurocidin levels (ng/ml) in periodontitis and in periodontal health. Each dot represents an individual sample, and the solidhorizontal lines indicate median values. Significant difference at ${ }^{*} \mathrm{p}<0.05$.

\section{DISCUSSION}

To the best of our knowledge, the present study demonstrated for the first time the salivary levels of azurocidin in periodontally healthy and periodontal diseased individuals. Generalized stage III or IV, grade $\mathrm{C}$ periodontitis patients had higher salivary azurocidin and TNF- $\alpha$ levels compared to periodontally healthy individuals.

There is adequate evidence that a significant portion of the inflammatory destruction in periodontal tissues results from the collateral damage by hyperactive neutrophils or neutrophils present in excessivenumbers. ${ }^{4}$ They can eliminate pathogens by phagocytosis and intracellular killing through oxidative and proteolytic

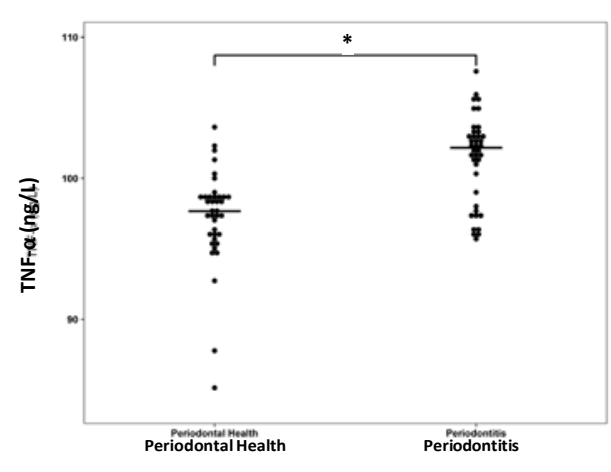

Figure 2: Saliva TNF- $\alpha$ levels (ng/L) in periodontitis and in periodontal health. Each dot represents an individual sample, and the solid horizontal lines indicate median values. Significant difference at ${ }^{*} \mathrm{p}<0.05$.

inflammatory reactions, and by extracellular mechanisms such as degranulation and release of neutrophil granulederived mediators like neutrophil extracellular traps. ${ }^{4,8}$ Azurocidin can be released both at a very early stage and at the late stage of inflammation due to its storage in two subsets of granules. ${ }^{8,9}$ Therefore, in the present study, increased salivary azurocidin levels in patients with periodontitis could be attibuted to enhanced neutrophils infiltration and azurocidin release in the inflamed periodontal tissues.

Similar to other neutrophil-derived antimicrobial proteins such as defensins, cathelicidin and lysozyme, azurocidin is also involved in host-pathogen interactions andimmunoregulation., ${ }^{5,9}$ Duetoitscationicpropertiesand hydrophobicity, azurocidin has strong affinity for LPS, a 
main component of the cell wall of gram-negative bacteria and neutralizes it during infection. ${ }^{9,10}$ Periodontal disease is also a polymicrobial inflammatory disease caused by especially Gram-negative periodontopathic bacteria. ${ }^{3}$ In the present study increased salivary azurocidin levels in periodontitis patients may be associated with elevated Gram-negative periodontopathic bacteria count and the strong affinity of azurocidin to LPS. Further mechanistic studies will provide more information about the role of azurocidin in periodontitis.

Although human saliva proteomic analysis helped in the identification of azurocidin ${ }^{24}$, there are no data about salivary azurocidin levels in patients with periodontitis. The role of azurocidin in periodontal disease was investigated in GCF studies. Leppilahti et al. ${ }^{14}$ have found that GCF azurocidin levels were higher in periodontitis sites relative to healthy sites and those levels showed high diagnostic accuracy $(\geq 0.90)$ for periodontitis. Choi et al. ${ }^{15}$ have found that GCF levels of azurocidin are higher in gingivitis and moderate periodontitis compared to severe periodontitis as well as periodontal health. The authors suggested that azurocidin might serve as a promising biomarker for a biomarker for the early detection of inflammatory periodontal destruction. In the same study ${ }^{15}$, it has been also demonstrated that azurocidin was expressed at a higher level in gingival tissues of periodontitis patients and inhibited the differentiation of macrophages to osteoclasts. Therefore, the authors speculated that elevated azurocidin levels during gingivitis may have a protective effect on alveolar bone during the early stages of periodontitis. On the other hand, increased alveolar bone loss during later stages of periodontitis could be due to decreased azurocidin levels and lack of its protective effect in severe periodontitis. ${ }^{15}$ Guzman et al. ${ }^{16}$ reported decreased GCF azurocidin levels after non-surgical periodontal treatment inchronic periodontitis. In agreement with those studies ${ }^{14-16}$ increased salivary azurocidin levels in periodontitis and positive association with all clinical periodontal parameters might reflect the potential association of azurocidin with periodontal inflammation.

In addition to its antimicrobial activity, azurocidin also contributes to enhance the LPS-induced induction of proinflammatory cytokines such as TNF- $\alpha$, IL-6 and IFN- $y$ from monocytes and macrophages via $\beta 2$ integrins. ${ }^{9,11}$ TNF- $\alpha$, the well-known marker of periodontal inflammation and alveolar bone resorption ${ }^{25}$, has been found increased levels in GCF and saliva of patients with periodontal disease ${ }^{18}$. It causes connective tissue and alveolar bone destruction by enhancing matrix metalloproteinase secretion and osteoclast formation. ${ }^{25}$ Similar to previous studies ${ }^{26,27}$, in the current study periodontitis patients had elevated salivary TNF- $\alpha$ levels and its positively correlation with azurocidin may provide further support for the previous studies reporting that azurocidin enhanced the LPS-mediated proinflammatory cytokines release from monocytes and macrophages.

The present study had some limitations. Given the cross-sectional nature of the study, causality cannot be established between biomarker concentrations and periodontal status. Another limitation may be the lack of gingivitis group. Gingivitis group might allow us to compare how azurocidin and TNF- $\alpha$ are involved in the destructive process during the periodontal disease progression. Finally, the lack of GCF and serum analyses may be considered as a limitation. The correlations among GCF, serum and salivary biomarker levels might provide further information regarding the role of azurocidin and TNF- $\alpha$ in periodontal inflammation.

\section{CONCLUSIONS}

To the best of our knowledge, the present study demonstrated for the first time the salivary levels of azurocidin in patients with peridontitis and also in periodontally healthy individuals. Within the limitations of this study, elevated salivary levels of azurocidin in patients with generalized stage III-IV, grade C periodontitis and its positively correlations with wholemouth clinical periodontal parameters and TNF- $\alpha$ implies that salivary azurocidin levels may involved in periodontal inflammation and may be useful to discriminate periodontitis to periodontal health. Further investigations with larger sample size are needed to elucidate the potential relationship of salivary azurocidin and TNF- $\alpha$ levels with periodontalinflammation.

\section{ACKNOWLEDGMENTS}

The authors thank to Research Assistant Semiha Özgül from the Department of Biostatistics and Medical Informatics, Faculty of Medicine, İzmir Ege University for statistical analyses. This work is supported by the Scientific Research Project Fund of Aydin Adnan Menderes University under the project number DHF-19014. 


\section{REFERENCES}

1. Flemmig TF. Periodontitis. Ann Periodontol 1999;4:32-38.

2. Kinane DF, Preshaw PM, Loos BG. Hostresponse: understanding the cellular and molecular mechanisms of host-microbial interactions-consensus of the Seventh European Workshop on Periodontology. J Clin Periodontol 2011;38 Suppl 11:44-48.

3. Mombelli A. Microbial colonization of the periodontal pocket and its significance for periodontal therapy. Periodontol 2000 2018;76:8596.

4. Herrmann JM, Meyle J. Neutrophil activation and periodontal tissue injury. Periodontol 2000 2015;69:111-127.

5. Gorr SU, Abdolhosseini M. Antimicrobial peptides and periodontal disease. J Clin Periodontol 2011;38 Suppl 11:126-141.

6. Türkoğlu $\mathrm{O}$, Emingil $\mathrm{G}$, Kütükçüler N, Atilla G. Evaluation of gingival crevicular fluid adrenomedullin and human neutrophil peptide 1-3 levels of patients with different periodontal diseases. J Periodontol 2010;81:284-291.

7. Ertugrul AS, Sahin H, Dikilitas A, Alpaslan NZ, Bozoğlan A, Tekin Y. Gingival crevicular fluid levels of human beta-defensin-2 and cathelicidin in smoker and non-smoker patients: a cross-sectional study. J Periodontal Res 2014;49:282-289.

8. Tapper H, Karlsson A, Mörgelin M, Flodgaard H, Herwald H. Secretion of heparin-binding protein from human neutrophils is determined by its localization in azurophilic granules and secretory vesicles. Blood 2002;99:1785-1793.

9. Soehnlein O, Lindbom L. Neutrophil-derived azurocidin alarms the immune system. J Leukoc Biol 2009;85:344-351.

10. Almeida RP, Vanet A, Witko-Sarsat V, Melchior M, McCabe D, Gabay JE. Azurocidin, a natural antibiotic from human neutrophils: expression, antimicrobial activity, and secretion. Protein Expr Purif 1996;7:355-366.
11. Heinzelmann M, Platz A, Flodgaard H, Polk HC Jr, Miller FN. Endocytosis of heparin-binding protein (CAP37) is essential for the enhancement of lipopolysaccharide-induced TNF-alpha production in human monocytes. J Immunol 1999;162:42404245.

12. Linder A, Arnold R, Boyd JH, Zindovic M, Zindovic I, Lange A et al. Heparin-Binding Protein Measurement Improves the Prediction of Severe Infection With Organ Dysfunction in the Emergency Department. Crit Care Med 2015;43:2378-2386.

13. Caseiro A, Ferreira R, Quintaneiro C, Pereira A, Marinheiro R, Vitorino R et al. Protease profiling of different biofluids in type 1 diabetes mellitus. Clin Biochem 2012 ;45:1613-1619.

14. Leppilahti JM, Hernández-Ríos PA, Gamonal JA, Tervahartiala T, Brignardello-Petersen R, Mantyla $\mathrm{P}$ et al. Matrix metalloproteinases and myeloperoxidase in gingival crevicular fluid provide site-specific diagnostic value for chronic periodontitis. J Clin Periodontol 2014;41:348-356.

15. Choi YJ, Heo SH, Lee JM, Cho JY. Identification of azurocidin as a potential periodontitis biomarker by a proteomic analysis of gingival crevicular fluid. Proteome Sci 2011;28;9:42.

16. Guzman YA, Sakellari D, Papadimitriou K, Floudas CA. High-throughput proteomic analysis of candidate biomarker changes in gingival crevicular fluid after treatment of chronic periodontitis. $J$ Periodontal Res 2018;53:853-860.

17. Podzimek S, Vondrackova L, Duskova J, Janatova T, Broukal Z. Salivary Markers for Periodontal and General Diseases. Dis Markers 2016;2016:9179632.

18. Ghallab NA. Diagnostic potential and future directions of biomarkers in gingival crevicular fluid and saliva of periodontal diseases: Review of the current evidence. Arch Oral Biol2018;87:115-124.

19. Teles RP, Likhari V, Socransky SS, Haffajee AD. Salivary cytokine levels in subjects with chronic periodontitis and in periodontally healthy individuals: a cross-sectional study. J Periodontal Res 2009;44:411-417. 
20. Newbrun E. Indices to measure gingival bleeding. $J$ Periodontol 1996;67:555-561.

21. Turesky S, Gilmore ND, Glickman I. Reduced plaque formation by the chloromethyl analogue of victamine C. J Periodontol 1970;41:41-43.

22. Tonetti MS, Sanz M. Implementation of the new classification of periodontal diseases: Decisionmaking algorithms for clinical practice and education. J Clin Periodontol 2019;46:398-405.

23. Navazesh M. Methods for collecting saliva. Ann N $Y$ Acad Sci 1993;694:72-77.

24. Denny P, Hagen FK, Hardt M, Liao L, Yan W, Arellanno $\mathrm{M}$ et al. The proteomes of human parotid and submandibular/sublingual gland salivas collected as the ductal secretions. $J$ Proteome Res 2008;7:1994-2006.

25. Preshaw PM, Taylor JJ. How has research into cytokine interactions and their role in driving immune responses impacted our understanding of periodontitis? J Clin Periodontol 2011;38 Suppl 11:60-84.

26. Frodge BD, Ebersole JL, Kryscio RJ, Thomas MV, Miller CS. Bone remodeling biomarkers of periodontal disease in saliva. J Periodontol 2008;79:1913-1919.

27. Gümüş P, Nizam N, Lappin DF, Buduneli N. Saliva and serum levels of B-cell activating factors and tumor necrosis factor- $\alpha$ in patients with periodontitis. J Periodontol 2014;85:270-280. 